\title{
Critical Analysis and Evaluation of the UAE Twelfth Grade Students' Language Instructional Material Based on the Set Goals and Objectives
}

\author{
Haytham M. Badr \\ Faculty of Education, The British University in Dubai (BUiD), Dubai, UAE
}

\begin{abstract}
Textbook is in the heart of any language teaching and learning program as it relieves some pressure placed on teachers' shoulders, provides students with a sense of progress and cohesion as well as providing education systems with the main structure by which they work and function. Therefore, great attention is paid to this critical area of research by syllabi developers and designers in addition to educationalists, scholars and researchers as a way to improve second language teaching and learning. One of main areas that concerns with the development of textbooks is to evaluate such textbooks to meet students' needs in accordance with the intended goals and objectives. The current research focuses on evaluating the UAE twelfth grade students' language textbook to check its compatibility, in terms of layout, topic and design, with the goals and objectives as set by the UAE educational process's decision makers. Some recommendations for the effective use of the current instructional material as well as some suggestions for future research are provided.
\end{abstract}

Index Terms — content-based syllabus, ESL, theme-based model

\section{INTRODUCTION}

\section{A. Background of the Study}

In the field of language education, many approaches to syllabus design are developed by different researchers and developers in order to enhance students' learning of the target language, and these approaches, according to White (2005), have three main bases; the content-based approach which requires structural, situational, informational (topic), functional or functional-notional focus, the skill-based approach which requires the focus on language productive/receptive skills or language acquisition skills and the method-based approach which requires process or procedural focus. Adding to this, Graves (2007) stresses that these approaches are not fixed to some designs or certain procedures but sometimes they are adapted to suit the goals and objectives as set by decision makers of the educational process. He goes on to say that this action or procedure also requires other adaptations or modifications in the studied/ taught material.

In this regard, Nunan (2007) emphasizes the importance of assessing instructional materials to check the suitability of the content to the set goals and objectives before conducting any modifications or adaptations on the content. He continues to say that the set goals and objectives should, at all times, reflect students' needs to enhance their motivation towards learning or acquiring the learnt/taught language. Other advantages are highlighted by McDonough and Shaw (2012) who say that conducting continual assessments or analyses of materials based on students' needs as formulated and presented in the set goals and objectives is important to prepare students to deal with future academic and professional challenges or any other challenges of particular interest to them.

Paying particular attention to our assessed material, we find that the content is organized, structured and designed around some thematic units and topics, and according to White (2005), Nunan (2007) and Snow and Brinton (2017), the instructional material that focuses on thematic units and topics is an instructional material designed in accordance with the content-based approach. For this reason, the content-based approach will constitute the general framework through which the suitability of the content to the set goals and objectives is investigated and assessed.

\section{B. Characteristics of the Content-based Approach}

Richards (2017) and Snow and Brinton (2017) define the content-based approach as the product of continual and purposeful development of different approaches to syllabus design from acquiring the target language through studying the linguistic features of that language to acquiring the target language through studying the content. Through the content-based approach, Nunan (2007) explains that students acquire the target language if they are exposed to a number of different topics and academic texts in a very organized way. The topics and activities in the content-based approach, according to Richards and Rodgers (2015), should be authentic and related to real-life situations in order to motivate students to learn the content and should also serve the specific objectives which revolve mainly around developing students' cognitive and linguistic skills and especially the communicative language skills.

Moreover, the work done by Haley and Austin (2014) gives more insights into our understanding of the characteristics of the content-based approach when they say that both language and content should be integrated in any 
material designed according to the content-based approach with the aim of improving students' linguistic skills, enhancing their cognitive skills as well as developing their academic language proficiency skills. They continue to say that this integration leads to three different models constituting a continuum; (1) the theme-based model, in which the target language is learnt or acquired through the content, (2) the shelter model, in which the content is learnt or studied through the target language, (3) the adjunct model, in which equal attention is given by designers to both language and content.

\section{Rationale Aim, Objectives and Scope of the Study}

As stated above, the successful modification or development of any instructional material depends primarily on the suitability of the content to the goals and objectives as determined by decision makers of the educational process based on students' needs analysis or assessment. In this regard, literature shows no attempts by researchers or other concerned developers or designers to evaluate the suitability of the current material to the set goals and objectives in the UAE context. Therefore, this study is going to be a unique study as being the first study, to the best of the researcher's knowledge, which looks into the appropriateness of the current material for the intended goals and objectives based on students' needs to maximize students' benefit from the current material.

By conducting this study, the researcher expects to arrive at conclusive answers about the suitability of this material to the intended goals and objectives. Moreover, he will be able to identify the strengths and weaknesses of the current material and provide suggestions for improvement if necessary. Furthermore, the significance of this study extends from improving the investigated material local-wide to improving it nation-wide as this material is circulated by the UAE Ministry of Education to be used at all 12th grade private and governmental schools that adopt the MOE curriculum. Finally, and to make this study more intensive, the researcher examines the current material in terms of the suitability of the layouts, topics and design to the set goals and objectives.

\section{Research Question}

To what extent are the current material's layouts, topics and design suitable for the set goals and objectives?

\section{LITERATURE REVIEW}

\section{A. Gradual Development of Language Syllabi Types}

Literature shows argument among researchers or contradiction in their views towards the nature of language and language learning based on their classifications of the different types of language syllabi. The following lines shed light on the gradual development of the different types of language syllabi explaining how they see language and language learning to be able to identify the location of the content-based syllabus among other language syllabi and fully understand its views towards language and language learning.

Literature indicates that language syllabi are first divided by Wilkins (1985) into two types; analytic and synthetic types. According to him, the first type includes three syllabi; the functional syllabus, the notional syllabus and the situational syllabus, in which syllabus designers should pay special attention to what students need from the target language. He continues to say that students, in this first type, acquire the target language when they are exposed to it in proper contexts, and this exposure should be in the form of chunks. Wilkins adds that the content should focus on developing the communicative skills as a starting point towards acquiring the target language, and this content should vary to encompass different academic topics, themes or situations. Unlike the analytic type, Wilkins insists that students, in the synthetic type, acquire the target language when they are exposed to it in the form of small parts. Language in this later type is viewed as a set of rules, and learning happens when such rules are studied in a gradual manner from the simplest to the most complex ones.

Later on, White (2005) divides language syllabi into two different types; (A \& B) types. According to him, the question about the language skills to be learnt should be the starting point for the (A) type, while the question about how language skills are learnt should be the starting point for the (B) type. He goes on to say that the first type can be called an "interventionist" approach as designers of this type intervene in designing the syllabus from the very beginning by putting some pre-determined language goals and objectives to direct teachers' attention to such goals and objectives when teaching the content, while the (B) type can be called a "non-interventionist" approach as no goals or objectives are pre-determined by syllabus designers as the best way to acquire the target language, according to this later type, is through the exposure to authentic materials in natural environments.

More recently, and as a result of the changes in researchers' views towards language and language learning, language syllabi are divided by Nunan (2007) into two new types; the product syllabus type and the process syllabus type. According to Nunan, the product syllabus type includes three different syllabi; the functional-notional, the situational and the structural syllabi, in which particular attention should be given by designers to the activities that enhance the language skills or the knowledge that students should acquire. He continues to say that language in the structure syllabus is acquired through the exposure to some certain forms of that language, and language in the situational syllabus is acquired through the exposure to authentic and real-life situations, while language in the functional-notional syllabus is acquired through the exposure to a combination of language forms and authentic situations. However, 
Melrose (2015) among others criticizes this type of language syllabi for encouraging teachers to use pre-conceived language scripts in ESL classes.

According to Nunan (2007), the process syllabus type includes also three different syllabi; the content-based syllabus, the task-based syllabus and the procedural syllabus. Language in this type is seen as a process through which the new language skill or knowledge is acquired. Nunan goes on to define each syllabus by saying that the content-based syllabus focuses on integrating both language and content in an instructional material to foster students' both cognitive and language skills. He adds that the instructional material in the task-based syllabus is structured around some communicative tasks to be performed by students, while the instructional material in the procedural syllabus is structured around some assumptions and conclusions to be drawn by students through the exposure to various tasks.

\section{B. Theoretical Framework of the Study}

\section{Theory of language:}

There are three main assumptions about the nature of language, and these assumptions are summarized in the following lines. Firstly, language is text and discourse-based implying the importance of focusing in instructional materials on the linguistic features that make text types and speech events coherent and cohesive. In other words, language is seen as a medium to learn the academic content through the study of discourse and textual structure of written texts such as book chapters, descriptions or reports, or of speech events such as discussions, lectures and meetings. Secondly, language use involves the study of the four language skills together by focusing on some selected topics and activities to enhance language, knowledge and thinking skills. Thirdly, language is purposeful; namely, language is used to serve specific purposes and these purposes may be social, vocational, academic or recreational, but whatever the purpose is, the content in the theme-based model or the language in the shelter model comes to serve this purpose.

\section{Theory of language learning:}

The integration of both language and content in students' textbooks or in a syllabus is first introduced in the Krashen's theory of comprehensible input, in which language is best acquired if students are exposed to considerable amounts of inputs that are understandable and, at the same time, are a little above students' current language level. Moreover, this theory suggests providing L2 students with the same environment as provided to L1 students in order for language learning to occur. The emphasis in this theory is given to language meaning rather than language form as language form can be acquired spontaneously when students are exposed to the input that is considerable and comprehensible.

The constructivist theory as first developed by Piaget is an expansion of the Krashen's theory of comprehensible input, in which the input, characterized as slightly above students' current level, should be well-constructed and wellrepresented in students' mind in order for language learning to happen. The starting point in designing the syllabus is the question about what is known about the input. The input, according to this theory, should also be typified as authentic, interesting and suitable for students' age and educational level to achieve effective language learning.

The social constructivist theory, as developed by Vygotsky, is considered a further expansion of the Krashen's theory of comprehensible input, in which the input, typified as considerable and slightly above students' current level, should be socially shaped by students' interaction. According to this theory, students will be able to construct some new concepts and ideas about the new knowledge if they are fully involved in classroom activities using that knowledge, and the result is better linking the new knowledge to the one that exists in students' mind, leading to effective language learning. The starting point in designing the syllabus is the same starting point as the constructivist theory, but the content here should be designed to include lots of communicative activities that encourage students to work in pairs or groups.

\section{Issues with the Content-based Approach.}

Literature shows some issues regarding the application of the content-based approach to achieve effective language learning. Firstly, many critics such as Harley (1990) and Sheen (1994) criticize the Krashen's theory of comprehensible input for focusing only on solving students' language fluency issues, keeping other language accuracy issues unsolved. To handle this issue, the content-based approach's instructional materials may be designed to include both meaningfocused and structure-focused instructions and activities to improve students' both fluency and accuracy levels of the learnt/ taught language.

Secondly, using the target language as a medium to learn or understand the content is another issue as it is recommended by many researchers; such as Ghorbani (2011) and Ovando and Combs (2017), to use both L1 and L2 in second language classes to enhance students' understanding of the content especially if students are classified as low language achievers. Notwithstanding, the mechanism by which syllabus designers can use to create dual language teaching materials is still a big challenge.

Lastly, the two-tiered skills model, as first introduced by Cummins (1979), is considered a big issue. This model suggests two different types of language skills; the basic interpersonal communication skills and the cognitive academic language proficiency skills. In this regard, Cummins indicates that skills of the first type are less complex and quicker to be acquired than skills of the second type, and thus, the adoption of integration to foster both students' language and 
knowledge skills is not appropriate. However, this issue can be solved if students are fostered to master the academic language skills before being exposed to the content to facilitate their understanding of the content.

\section{TEACHING ConteXT}

\section{A. Research Material and Research Site}

The current research material, attached as a separate document to this study, is scanned from the UAE $12^{\text {th }}$ grade students' textbook, "Bridge to Success", Borecki, Smith, Brettell, Cullinan, Al Baloushi and Behan (2018), third term material. It consists of three units covering the following three topics; environment, people and psychology, and life after school. Furthermore, the school, from which this instructional material is collected, is a very popular private school named "Al Dhaid private school" and located in Al Dhaid city, Sharjah, UAE. This school is accredited by the UAE Ministry of Education to provide teaching services for different academic subjects at its site including teaching English as a second language, and therefore, it is chosen by the researcher to be the current research site.

\section{B. The Intended Goals and Objectives}

The instructional material under investigation consists of three units all of which have one general aim and two specific objectives, and they all revolve mainly around expanding students' knowledge of the wider world by presenting different authentic topics, themes and situations in a very interesting way to enhance respect and interest in other cultures and increase the awareness of global citizenship. It also aims at developing students' language, thinking and knowledge skills to prepare them to cope with the latest updates and developments on various cultural and educational levels and to deal with future academic and professional challenges if or when encountered by them.

To explain this in details, the current instructional material aims at developing students' critical thinking and social skills, proactivity and self-confidence and cognitive and meta-cognitive abilities through a wide variety of contentbased academic texts and activities that motivate students to participate as active learners. It also aims at developing students' receptive and productive language skills to reach the competency level that enable them to meet future needs and challenges both academically and professionally by providing topics and creating situations that are authentic and related to the real life.

\section{Material's Evaluation}

McDonough and Shaw (2012) contend that the main purpose of analyzing or assessing any instructional material is to measure its suitability in relation to the general aims and specific objectives as set by decision makers of the educational process. Not only that, they go on to say that this procedure is usually followed by some recommendations towards any shortcoming or unsuitability as detected by assessors or developers. The researcher of this study allocates this section to analyze and assess the current research material in terms of the suitability of layout, topics and design to the set goals and objectives, while the following section is allocated to talk about areas of improvement, if necessary, to maximize students' benefit from the current material. Moreover, and in order to make the evaluation process more effective, a checklist, as suggested by McGrath (2016), in the form of some questions is fully developed by the researcher to help him focus on the current research objectives, and this checklist is annexed in the appendix (A) to this research.

\section{A. Material's Layout}

The current material attracts students' eyes to the key text elements and information using a variety of font and text highlight colors plus a large number of color images to explain or facilitate students' understanding of the content. These colors are harmoniously and consistently used by the designers of this material to please students' eyes and encourage them to read and study the content. Moreover, the material's font size is relatively large, allowing for students to read the content without difficulty leading to low pressure on the students' eyes and more focus, in return, on the content. Furthermore, the current material's designers extensively use single focal points and big and bold headline fonts to provide students with clear references and guide pages. In addition, white spaces are considered to achieve a more pleasing composition of the layout, and this is done by enlarging page margins and gutters and by increasing the white space between key page elements.

The above layout considerations, as taken care of by the current material's designers, are deemed important by many researchers (e.g., Mohanna, Cottrell, Wall \& Chambers, 2017; Schröpfer et al., 2012; Stoller, 2002) to make any designed material readable and understandable. These considerations are also compatible with the current instructional material's goals and objectives which call for attractive, likable and comfortable layout to trigger students to read and focus on the academic content, resulting in a wider understanding of the presented topics and a better learning of the studied language skills.

\section{B. Material's Topics}

According to the principles of the content-based approach, the topics should be authentic and linked to real life to trigger and prompt students to learn both language and knowledge skills. They should also suit students' current educational level and cognitive abilities to ensure well-representation and well-construction of the new information or knowledge in students' minds resulting in content and language learning. In this regard, the content-based approach 
calls for gradual exposure of topics so that the easiest topics that students have previous background about are first presented to easily link the new information to the existing one leading to well- representation and well-construction of the new information in students' mind. The first unit talks about the following topics: "the great pacific, garbage patch, recycling and endangered species", and the second unit discusses the following topics: "personality profiles, personality types, body language, society and personal space", while the third unit tackles the following topics: "self-assessment quiz, magazine article on smells and five year plan".

A deep look at the material' topics shows that, in contrast to the first unit (unit 10 in students' textbook), the second and third units (unit 11 and unit 12 in students' textbook) are very authentic and related to real life, and also touch students' core needs of learning and prepare them for future challenges. It is also noticed that the topics in the three units can be considered suitable for students' educational and cognitive level as students of their age, between 17 and 18 years old, are able to, according to Piaget's view of learning, think logically and abstractly, believe in the unseen and accept situations they do not know about or hypotheses unknown to exist for them (Slavin, 2009).

Nevertheless, Niaz (1997) and Piekny and Maehler (2012) among others challenge Piaget's view of this last learning stage, called the formal operation stage, when they say that some people never reach this stage of learning. Based on that, the topics in the first unit may have to be adjusted to suit students of low proficiency levels. Adding to this, it is noticed that the topics of the first units have nothing to do with the topics of the second and third units, and the material's topics are not even presented gradually in terms of difficulty level, which are considered important by Richards and Rodgers (2015) to allow for cohesive transition of concepts, skills, structures and vocabulary. It is quite apparent from the investigated material that the topics of the first unit require more technical processes than the topics of the second and third units and at the same time supposes knowing some concepts, structures, vocabulary and skills about the content.

\section{Material's Design}

\section{Syllabus design:}

The current material is typically designed using the theme-based model of the content-based approach as it uses the content in the form of some selected topics, instructional sentences and written texts as a medium to learn the target language, the English language in our case, with the aim of developing students' language and knowledge skills in full agreement with the intended goals and objectives as set by decision makers of the educational process. Moreover, and based on the classification of Haley and Austin (2014), the current instructional material is suitable for students' educational level in congruent with the work of Richards and Rodgers (2015) in which the theme-based syllabus model can be designed for students at both elementary and secondary levels.

\section{Types of teaching and learning activities:}

According to the theme-based model of the content-based approach, the activities should be designed to develop the four basic language skills with much more focus on the communicative language skills along with the other social and knowledge and thinking skills through teacher-student and student-student interaction. This idea is elaborated in the works of Stoller (2002) and Snow and Brinton (2017) by saying that the content-based activities should be directed towards improving language skills, discourse organization, vocabulary building, study skills and communicative interaction.

A closer look at the current material shows that a good number of activities is designed, approximately 35 activities per unit, to improve the four basic language skills along with the other social, knowledge and thinking skills in agreement with the set goals and objectives. To provide a thorough and accurate analysis of the designed activities, the reading activities are designed to improve students' word and sentence analysis skills as well as developing their abilities to explore new vocabulary meanings and grammar functions. The speaking and writing activities are designed to enhance students' communicative skills through work in groups or pairs by creating different situations and events triggering students to produce richer language. The listening activities are designed to improve students' understanding of the spoken language through listening to a variety of academic topics. Moreover, the questions in the activities are perfectly designed to suit both low-achieving and high-achieving students by providing simple questions that require short answers, less active participation and lower mental processes and other complex questions that require richer answers, more active participation and higher mental processes as appears in the true/false questions and other WH questions of the current material's activities.

Nevertheless, and despite all above, it is noticed that the activities of the current material are equally distributed to developing the four language skills without paying particular attention to developing the productive language skills as considered crucial by Haley and Austin (2014) to acquire or learn the target language. It is also noticed from the investigated material that students' social skills are enhanced only in the activities designed to develop the productive language skills, and this is against one of the core principles of the content-based approach in which low-achieving students are always scaffolded by their classmates and are active learners during all classroom language activities. In this regard, teachers and especially inexperienced teachers are advised by McCafferty, Jacobs and Iddings (2006) and Orlich et al. (2013) to be very careful when adopting massive use of group work activities as this may result in teachers' distraction from focusing on the intended goals and objectives.

The role of instructional materials: 
The material in the content-based approach, according to Snow and Brinton (2017) and Richards and Rodgers (2015), should be authentic in order for language learning to happen, and the material's authenticity occurs when two conditions are provided; (1) it should be like the materials used in teaching the native language, (2) it has a collection of different sources; such as magazine articles, newspaper and any other media materials, that are not basically used for language teaching purposes. Snow and Brinton (2017) and Stoller (2002) advocate the second condition by saying that the content-based material should include as much instructional media (e.g., CDs and/or audiotapes) as possible to enhance the authenticity of the studied/ taught materials. Moreover, Richards and Rodgers (2015) argue that materials' comprehensibility is of the same importance as material's authenticity. To put this in simple words, instructional materials may have to be designed to include some linguistic simplifications to make the content understandable. In this regard, Gagné (2007) and Snow and Brinton (2017) suggest providing some linguistic tips, strategies or guides to help students understand the content.

A deep look at the investigated material shows that it provides authentic sources using audiotapes or CDs to enhance students' listening skills. It also uses lots of linguistic simplifications whether at the right side or at the bottom of pages to simplify and summarize the content. However, using a collection of different sources; such as magazine articles and newspaper, is not much seen in the assessed material to further enrich the material with authentic sources as important by Snow and Brinton (2017), Richards and Rodgers (2015) and Gagné (2007) to foster language learning. Furthermore, the suggested instructional media are not heavily used confining their use to developing the listening skill, while it can also be used to provide authentic environment to improve the other three language skills (Stoller, 2002). In the same vein, Stoller suggests having access to the modern technologies; such as computer and internet, in classrooms not only to provide authentic environment, but also to widen students' horizons and encourage their curiosity about the wider world to meet the current material's general aim as set by decision makers of the educational process.

\section{CONCLUSIONS, AREAS OF IMPROVEMENT, AND RECOMMENDATIONS}

The current material is well-structured and well-designed using the content-based approach following the themebased model to achieve effective language and content learning with the aim of preparing students for their future both academically and professionally. To achieve this aim, a variety of topics are selected and lots of activities are designed to improve students' cognitive capabilities and mental abilities as well as developing them in the four language skills. Moreover, it provides authentic sources and linguistic simplifications to enhance students' content understanding and language learning in agreement with the intended goals and objectives as set by the educational process's decision makers. Notwithstanding, our analysis and evaluation of the current material reveal some points to be taken into account by future potential developers or designers to maximize students' benefit from this material, and these points are recapitulated in the following lines.

Firstly, the current instructional material seems to enhance teacher-centered instruction by focusing much more on making the content understandable through some linguistic simplifications and confining students' participation to some activities to develop their communicative skills in contradiction with the most recent teaching strategies in which students are always active and independent in all classroom activities. Secondly, efforts to overcome the limitations of the content-based approach in the way that it pays only attention to language meaning rather than language form are tangible by designing a large number of activities to improve the four basic language skills, but, in doing so, these efforts fail to pay specific attention to the communicative language activities as crucial to achieve effective language learning.

Thirdly, the material's authenticity is another issue as the current material provides authentic sources only in the listening activities through some audiotapes or CDs to enhance the listening skill, while other authentic sources; such as newspaper, article magazine and other online activities, can also be used to enhance the other three language skills. Fourthly, the first unit (unit 10 in students' course book) fails to deal with students' disparities in terms of their cognitive capabilities and mental abilities as it provides inputs suitable only for high achievers. Besides, the content of the first unit is not linked to the other two units and even much more difficult to learn than them in contrast to the principles of the content-based approach in which any new inputs should be closely connected to avoid confusion and gradually presented in terms of difficulty level to facilitate students' construction and representation of new inputs.

Therefore, the current material may have to be re-designed to include more activities that encourage peer or group work with paying more attention to the speaking and writing activities. Moreover, the current material may be adjusted to include authentic reading, writing and speaking sources to enhance the acquisition of the four language skills as emphasized by principles of the content-based approach. Finally, the topics in the first unit may be changed to suit lowachieving students, but before doing so, future potential designers have to reach the mechanism by which they can judge students' zone of proximal development to be able to design materials suitable for both high and low achievers. 


\section{ApPendix. A Evaluation Checklist}

\begin{tabular}{|c|c|}
\hline Assessed Elements & Comments \\
\hline $\begin{array}{l}\text { Material's layout } \\
\text { - Does the material attract students' eyes using font and text highlight colors? } \\
\text { - Does the material use color images to explain or facilitate students' understanding of the } \\
\text { content? } \\
\text { - Is the texts' font size readable? } \\
\text { - Are the focal points and bold headline fonts used to provide students with clear references? } \\
\text { Material's topics } \\
\text { - Are the materials' topics authentic and related to real life? } \\
\text { - Are the topics suitable for students' cognitive and educational levels? } \\
\text { - Are the topics connected to each other and arranged or presented in terms of level of } \\
\text { difficulty? } \\
\text { - Do the topics challenge students' experience and knowledge in agreement with the intended } \\
\text { goals and objectives? } \\
\text { Material's design } \\
\text { - What kind of approaches used in designing the current material? } \\
\text { - Is the adopted approach congruent with the set goals and objectives? } \\
\text { - Does the syllabus design compatible with students at a 12-grade level? } \\
\text { - How many activities are designed, and are they directed to enhance students' language and } \\
\text { knowledge skills? } \\
\text { - Do the designers use different types of questions in the activities to encourage both low- } \\
\text { achieving and high-achieving students to participate in classroom activities? } \\
\text { - Do the activities pay special attention to the productive language skills as stressed by the } \\
\text { content-based approach to foster effective language learning? } \\
\text { - Is the material authentic and if so, what are the types of sources used to make the material } \\
\text { authentic? } \\
\text { - Is the material comprehensible, and if so, what are the strategies used to make the material } \\
\text { comprehensible? } \\
\text { - Does the current material encourage using the modern technologies; such as computer and } \\
\text { internet, to facilitate both language and content learning? }\end{array}$ & \\
\hline
\end{tabular}

\section{REFERENCES}

[1] Cummins, J. (1979). Linguistic interdependence and the educational development of bilingual children. Review of Educational Research, 49.2, 222-251.

[2] Gagné, R. M. (2007). Principles of instructional design (5th edn). Belmont, CA: Thomson/Wadsworth.

[3] Ghorbani, A. (2011). First language use in foreign language classroom discourse. Procedia: Social and Behavioral Sciences, 29, $1654-1659$.

[4] Graves, K. (2007). Designing language course: A guide for teachers. Boston: Heinle \& Heinle.

[5] Haley, M. H. \& T. Y. Austin. (2014). Content-based second language teaching and learning: An interactive approach (2nd edn). Boston: Pearson.

[6] Harley, B. (1990). The development of second language proficiency. Cambridge: Cambridge University Press.

[7] McCafferty, S. G., G. M. Jacobs \& A. C. D. Iddings. (2006). Cooperative learning and second language teaching. Cambridge: Cambridge University Press.

[8] McDonough, J. \& C. Shaw. (2012). Materials and methods in ELT (3rd edn). Hoboken: Wiley.

[9] McGrath, I. (2016). Materials evaluation and design for language teaching (2nd edn). Edinburgh: Edinburgh University Press.

[10] Melrose, R. (2015). The communicative syllabus: A systemic-functional approach to language teaching. London: Bloomsbury.

[11] Mohanna, K., E. Cottrell, D. Wall \& R. Chambers. (2017). Teaching made easy: A manual for health professionals (3rd edn). [S.1.]: CRC Press.

[12] Niaz, M. (1997). How early can children understand some form of "scientific reasoning"? Perceptual and Motor Skills, 85.3, $1272-1274$.

[13] Nunan D. (2007). Syllabus design. Oxford: Oxford University Press.

[14] Orlich, D. C., R. J. Harder, R. C. Callahan, M. S. Trevisan, A. H. Brown \& D. E. Miller. (2013). Teaching strategies: A guide to effective instruction (10th edn). Belmont, CA: Wadsworth Cengage Learning.

[15] Ovando, C. J. \& M. C. Combs. (2017). Bilingual and ESL classrooms: Teaching in multicultural contexts (6th edn). Lanham, Maryland: Rowman \& Littlefield International.

[16] Piekny, J. \& C. Maehler. (2012). Scientific reasoning in early and middle childhood: The development of domain-general evidence evaluation, experimentation, and hypothesis generation skills. British Journal of Developmental Psychology, 31.2, 153-179.

[17] Richards, J. C. (2017). Curriculum development in language teaching (2nd edn). Cambridge: Cambridge University Press.

[18] Richards, J. C. \& T. S. Rodgers. (2015). Approaches and methods in language teaching (3rd edn). Cambridge: Cambridge University Press.

[19] Schröpfer, T., J. Carpenter, S. Kennedy, L. Margolis, T. Mori, N. Tehrani \& P. Yeadon. (2012). Material design: Informing architecture by materiality. Basel: Birkhäuser.

[20] Sheen, R. (1994). A critical analysis of the advocacy of the task-based syllabus. TESOL Quarterly, 28.1, 127-147.

[21] Slavin, R. E. (2009). Educational psychology: Theory and practice (8th edn). USA: Pearson Education. 
[22] Snow, M. A. \& D. Brinton. (2017). The content-based classroom: New perspectives on integrating language and content (2nd edn). Ann Arbor: University of Michigan Press.

[23] Stoller, F. L. (2002). Project work: A means to promote language and content. In J. C. Richards \& W. A. Renandya (eds.), Methodology in language teaching: An anthology of current practice. Cambridge: Cambridge University Press, 107-119.

[24] White, R. V. (2005). The ELT curriculum: Design, innovation and management. Malden: Blackwell.

[25] Wilkins, D. A. (1985). Notional syllabuses: A taxonomy and its relevance to foreign language curriculum development. Oxford: Oxford University Press.

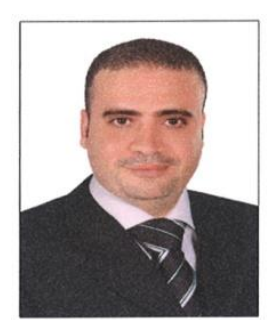

Haytham M. Badr was born in Mansoura, Egypt in 1983. Badr is currently studying as a Ph.D student in Education, TESOL at the British University in Dubai, United Arab Emirates. He achieved his master degree in Education, TESOL from the British University in Dubai in 2017, his two post-graduate diplomas in Education, curriculum and teaching methods/ English department from Tanta University, Egypt in 2007-2008 and his bachelor degree in simultaneous interpretation/ English department from Al-Azhar University, Cairo, Egypt in 2006.

He currently works both as an English language instructor and as an English-Arabic interpreter in AbuDhabi government, UAE. He also worked as an English instructor, translator, interpreter and English teacher in Mansoura University, Egypt. His research interests include L2 teaching and learning, discourse analysis, curriculum and innovation, educational policy, inclusive education and translation.

Mr. Badr is a member of a non-profit association based in Egypt to provide recommendations for the development of English instructional materials as well as providing free of charge English teaching services for indigents and a member of translators' association to improve different types of written translation through free online courses and discussions. 